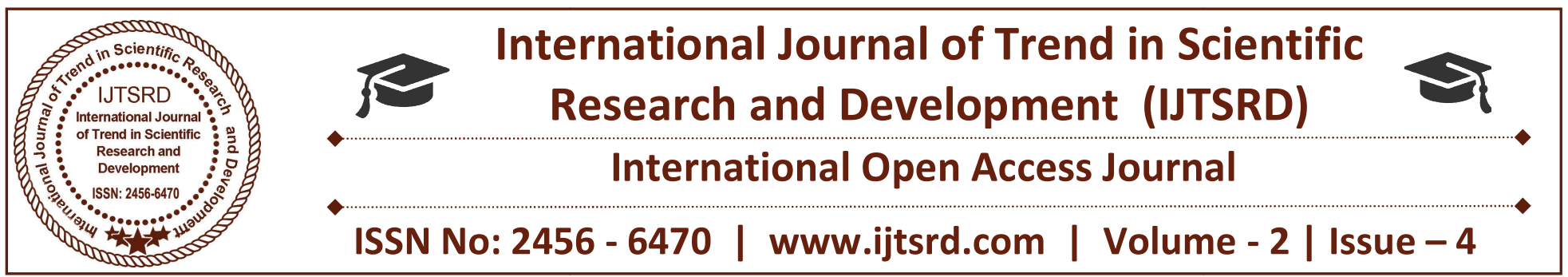

\title{
Study and Application of Watershed Management Techniques for Self Reliant Village (KHOR BASIN)
}

\author{
Vishal Karad, Ravindra Bade, Vinod Khade, \\ Shradha Ghorpade, Geetanjali Gajbhar, Ganga Abitkar \\ BE Civil, DIT (PIMPRI), Pune, Maharashtra, India \\ Mr. Sunil Deshpande, Mr. Vinayak B. Kale \\ Professor, Civil Engineering, DIT (PIMPRI), Pune, Maharashtra, India
}

\begin{abstract}
Land, water and vegetation are the three basic resources of the life support system. The effective conservation and management of land, water and vegetation resources aimed at obtaining optimum and sustained return from these resources without degrading them can be achieved by adopting watershed as basic unit of development. Watershed being a natural hydrological entity, it responds most effectively to various engineering, biological and cultural treatments. Monitoring of runoff and silt at the outlet of the watershed can help assess the impact of various treatments aimed at conserving soil and water, and protecting vegetation.
\end{abstract}

Keywords: watershed management techniques, weir, CCT, Recharge Well, ARCGIS

\section{INTRODUCTION}

The annual rainfall over India is computed to be 1170 $\mathrm{mm}$, which is much higher than the global average of $800 \mathrm{~mm}$. However, this rainfall in India occurs during short periods of high intensity and because of such high intensity and short duration most of the rain falling on the surface tends to flow away fast leaving little scope for re-charging of ground water resulting thereby lack of water in most part of the country even for domestic uses. (Rainwater Harvesting \& Conservation, Manual, India). Because of tremendous increase in Population, Urbanization and Industrializations, incline water demand in India. Lots of population is depends on agriculture and agriculture depends on monsoon. Study area is affect by erratic monsoon and water scarcity from last decade. Hence there is basic need to manage rain water trough different possible watershed management techniques implemented by government and local level. Watershed development is an important component of many countries rural development and natural resource management strategies. The Government of India spent over $\$ 6$ billion from 1996-2004 (World Resources Institute 2005).

Watershed development and watershed management are often used interchangeably. Watershed development refers to programs with technical interventions (planting trees, building check dams, etc.) to raise the productivity of certain resources and bring water resources under control. Watershed management refers to managing hydrological relationships in a watershed, which may involve protecting certain resources from degradation rather than making physical investments in their productivity.

This research shows a case study and application watershed management techniques for khor village. 
Study Area-

Study area lies in Pune District and surrounding area of Khor Villages in Daund taluka. The Latitudinal extension is $1824^{\prime} 22.38^{\prime \prime}$ 'North to $7444^{\prime} 21.78^{\prime \prime}$ North and Longitudinal extension is 750 4' 92 " East to 750 7' 50" East. rises near Dombewadi village. The total basin area is 11.97 sq.km.

\section{METHODOLOGY}

Methodology which is adopted this study technical watershed development guidelines are used which is given by Soil Conservation and Agriculture Department, Government of Maharashtra and Ministry of Rural Development, Government of India. All river and Tributaries are digitized from S.O.I. toposheets. Terrain maps are made by ASTER data which is downloaded from BHUVAN website and calculations of runoff and discharge theoretically and by ARCGIS software and further use it in the design purpose of watershed management structures.

\section{Site Selection Criteria for Water Harvesting Structure-}

To overcome water scarcity of study area various watershed management structures are proposed in hilly, plateau and lower reach in khor watershed i.e. continuous contour Trenches, check dams, weir and recharge wells.

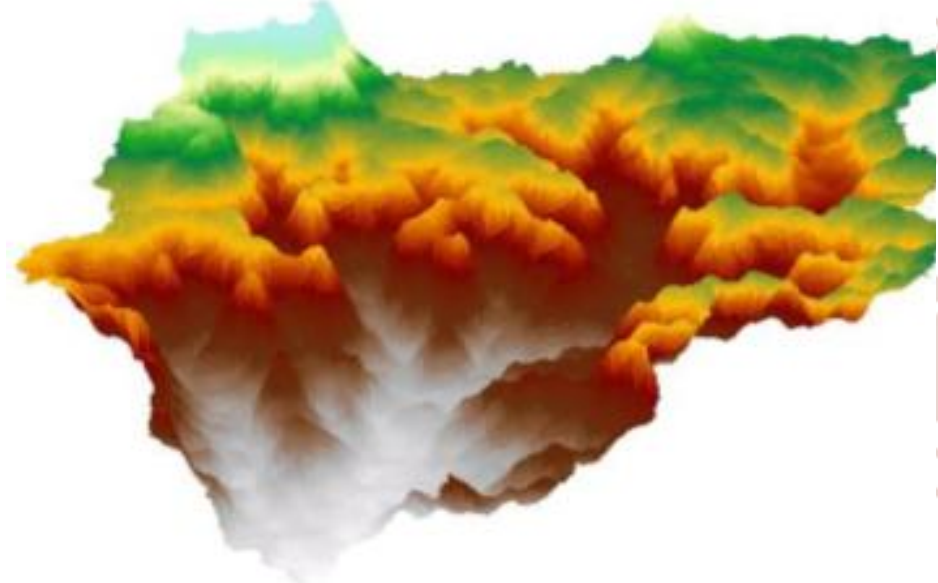

Figure.1 Digital Elevation Model of watershed

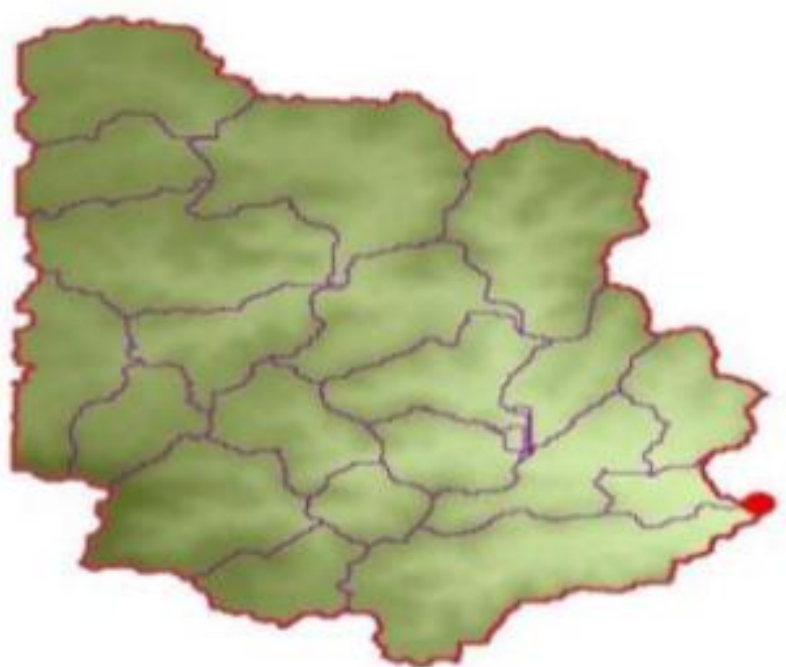

Figure. 2 watersheds surrounding to khor watershed

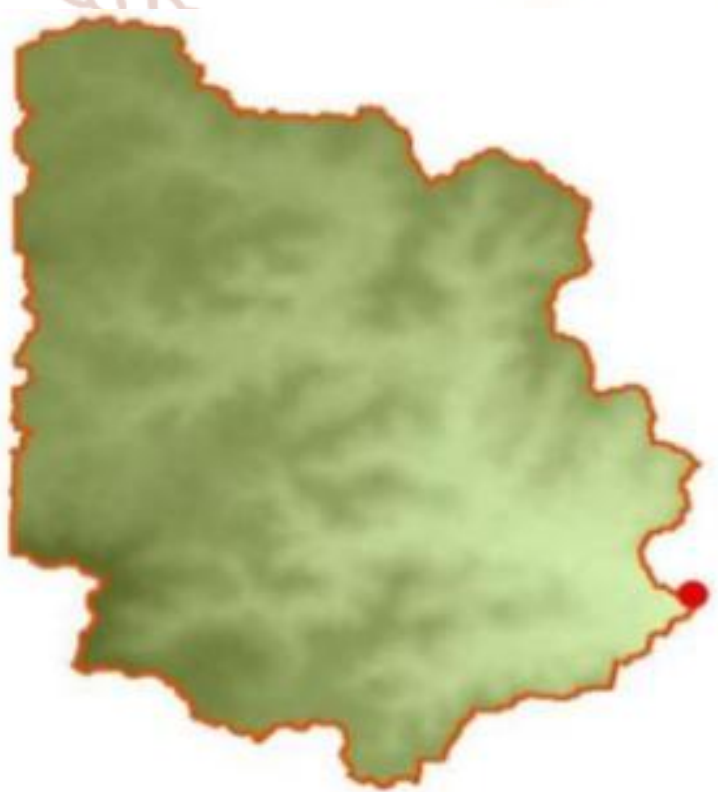

Figure.3 Slope Map of khor watershed

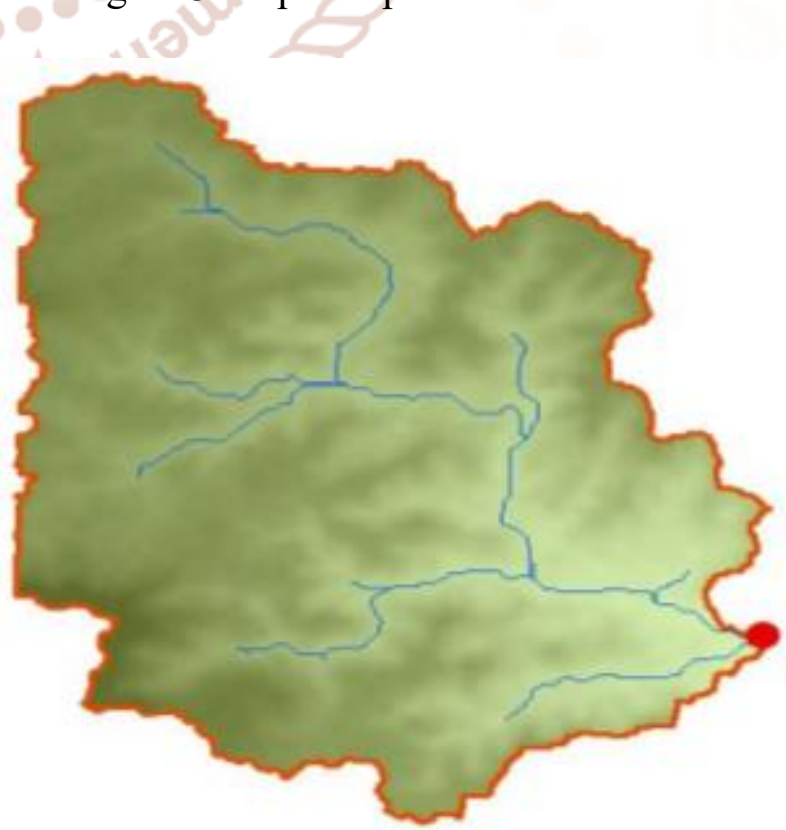

Figure.4 streams in khor watershed 


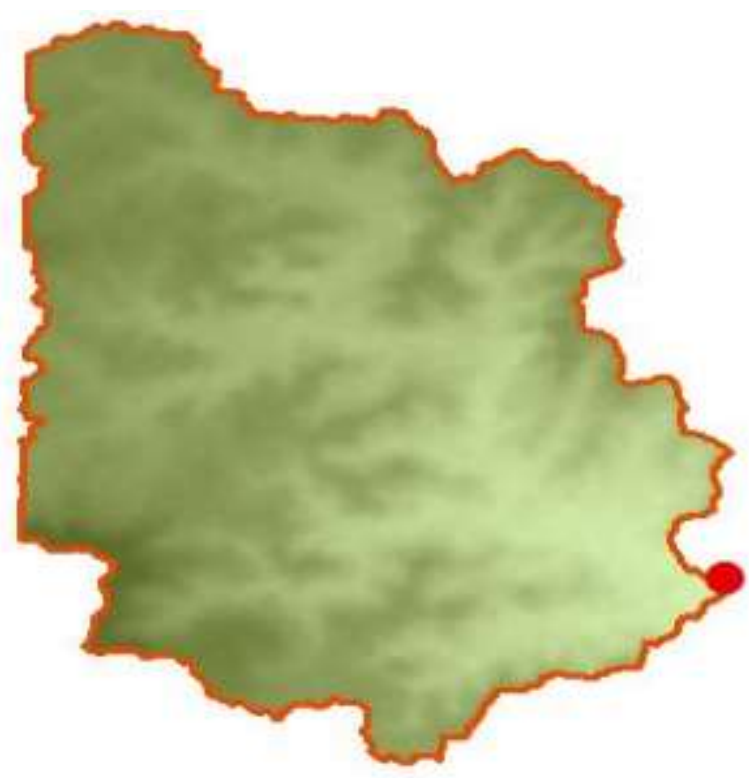

Figure.5 location of watershed outlet

rise behind the weir and then flow over it. if the jet of liquid passes over the weir springs free as it leaves the upstream face then the weir is known as sharp crested weir. Where the upstream floor level and the crest level are not the same, the crest may be provided flat at the top with a width of about $2 \mathrm{~m}$. An upstream slope of $2: 1$ to $3: 1$ shall be given depending on site conditions. For major projects, it is advisable to undertake model studies for obtaining the best shape for the crest. For weirs without shutters, the crest level shall be at the required pond level. For weirs with falling shutters, the crest level shall not be lower than $2 \mathrm{~m}$ below the elevation of the pond as the maximum height of the falling shutters is normally limited to 2 $\mathrm{m}$. It maybe suitably raised if possible, from consideration of passing the design flood discharge at the desired afflux and with the waterway provided. If the lowest crest level fixed in the above manner

DESIGN CRIETERIA FOR WATERSHED MANAGEMENT STRUCTURES PROPOSED: causes too much of afflux, the waterway of weir may be suitably increased.

\section{Continuous Contour Trenches:}

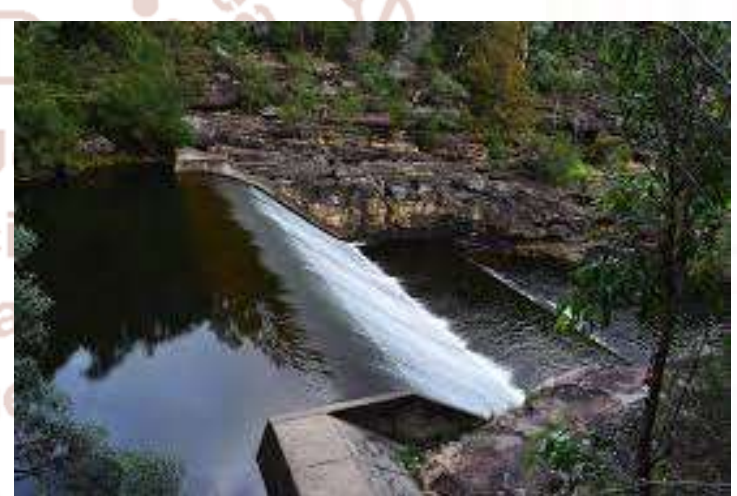

Figure.7 weir
Figure.6 Continuous Contour Trenches

Continuous Contour trench (CCT) is a trench dug along a contour line. CCTs are constructed in the ridge area, basically located in upper reaches of a micro watershed. This structure checks soil erosion, slowing down the velocity of runoff and improves soil moisture profile. (i) For this structure 5.71 to 14.04 degree slope area is suitable. (ii) If the slope is more than 14.04 degrees, one can't be dug contour trenches because of digging in high slope causes soil erosion. (iii) If the slope is less than 5.71 degrees, other structures other than contour trenches and CCT are best for such place (Govt. of India, 2007).

\section{Weir :}

It is a standard device for measurement of flow in open channel since last two centuries. It is an obstruction in the path of flow that causes the liquid to

\section{Check Dams :}

(i) Earthen or cement check dams can be constructed across bigger first order or second order streams. (ii) It should be constructed in areas of gentle slopes (less than 1.72 degrees). (iii) Depth of nala should be more than $1 \mathrm{~m}$. (iv) The soil downstream of the bund should not prone to water logging. (v) Vertical distance between two check dams should be more than $1 \mathrm{~m}$. (vi) It can be constructed in area having mix material.

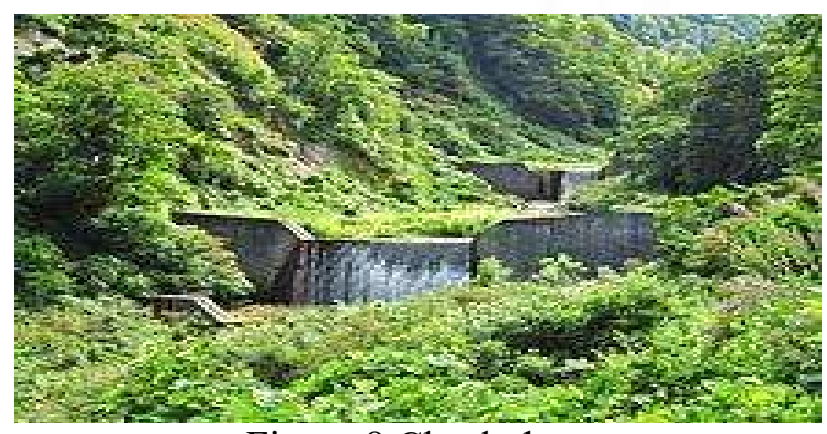

Figure.8 Check dam 


\section{Recharge well :}

Artificial recharge wells are engineered systems where surface water is put on or in ground for infiltration and subsequent movement to aquifer to augment ton groundwater resource. Other objectives of recharge well is to reduce land subsidence. The main advantage of recharge well is that they are inexpensive relative to other methods.the general dimensions for rainfall ranging from $600 \mathrm{~mm}$ to 900 $\mathrm{mm}$ are 3 feet diameter and depth 20 feet for every 1000 sq.m. each well can recharge 2500 lit/day to 1000 lit/day depending upon rainfall.
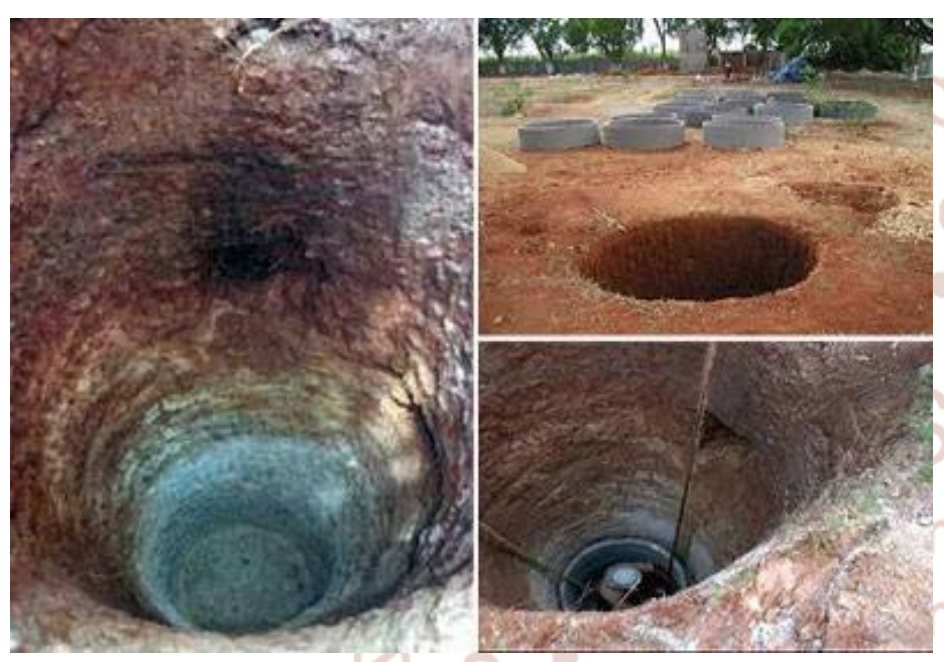

Figure.9 Recharge well

\section{Morphometric Analysis of khor watershed :}

\begin{tabular}{|l|l|l|}
\hline 1 & No. of stream order & 5 \\
\hline 2 & Catchment length $(\mathrm{km})$ & 8.97 \\
\hline 3 & Catchment Area (sq. km) & 11.96 \\
\hline 4 & Basin Relief $(\mathrm{m})$ & 155 \\
\hline 5 & Perimeter $(\mathrm{km})$ & 21.575 \\
\hline 6 & High Height $(\mathrm{m})$ & 690 \\
\hline 7 & Low Height $(\mathrm{m})$ & 535 \\
\hline 8 & Relative Relief $(\mathrm{m})$ & 17.27 \\
\hline 9 & Bifurcation Ratio & 0.833 \\
\hline 10 & Length Ratio & 1.38 \\
\hline 11 & Basin Stream length $(\mathrm{km})$ & 17.36 \\
\hline 12 & Drainage Density $(\mathrm{km} / \mathrm{sq} . \mathrm{km})$ & 1.50 \\
\hline 13 & Stream Frequency $(\mathrm{sq} . \mathrm{km})$ & 1.92 \\
\hline 14 & Circularity Ratio & 0.322 \\
\hline 15 & Elongation Ratio & 0.294 \\
\hline 16 & Length of overland flow & 0.75 \\
\hline 17 & Form Factor ratio & 0.272 \\
\hline
\end{tabular}

Table. 1
The Morphometric analysis is important in any hydrological investigation like assessment of groundwater potential ,Ground management, pedology and environmental assessment. Geomorphologists and hydrologists have recognized that certain relations are most important between runoff characteristics, and geographic and geomorphic characteristics of drainage basin systems. Various important hydrologic phenomena can be correlated with the physiographic characteristics of drainage basins such as shape, size, slope of drainage area, drainage density, length and size of the contributories etc. Morphometric analysis helps to understand relationship between basin area and topography of region that allows how we deals with natural system basically for land use e.g. water harvesting techniques applies on particular watershed.

\section{CONCLUSION}

Whatever water is getting to the area by rainfall it is enough for basic needs of human activities, yet also lost of area faces water scarcity problem in India. In case of Morphometry of this river has 5th stream order $\bigcirc$ with drainage length of $1053.04 \mathrm{Km}$. Bifurcation Ratio has indicated this area having hydrological and geological control. Shape of basin is elongated it means this river has flow very short period in monsoon and most of period is dry even there large number of tributaries are there. According to texture ratio and length ratio there is lots of erosion and soil loss, which control by continuous contour trenches. Morphological and geohydrological units are helpful for water harvesting. According to them 2 weir, 50 Continuous contour trenches(with bore holes of $0.5 \mathrm{ft}$. diameter and $30 \mathrm{ft}$. deep) and 10 recharge wells are suggested in study area.

\section{REFRENCES}

1) Pandurang D. Jankar 1 and Dr.Mrs.Sushma S. Kulkarni, "Watershed Management - A Case Study Of Madgyal Village", International Journal of Engineering Research \& Technology (IJERT), Vol. 2 Issue 7, July -( 2013).

2) Patil, Shivraj G, Wayal, AbhaykumarS,"Watershed Management in Rural Area -A Case Study",International Journal of Scientific Engineering and Research (IJSER), Volume 1, Issue 1.(2013)

3) Mrs. Vidula Arun

Swami, Dr.Mrs.SushmaShekharKulkarni," watershed management - A Means of sustainable 
International Journal of Trend in Scientific Research and Development (IJTSRD) ISSN: 2456-6470

Development - a case study", international journal of engineering science and technology (IJEST),(2011).

4) Mr.Nittin Johnson, Mr Govindaradjane $\mathrm{T}$. Sundrajan "Impact of watershed management on the ground water and irrigation potential - a case study (IJEST)(2013)

5) Ms.RadhikaPatil,Profhandargekar P.A. "watershed management in sangave village", (2015)(IJSRD)

6) Mr.ParagThakre ,Mr.RajA.Jadhav "watershed management a case study of tanda village" (2013)(IJITEE)(Volume 3 issue 4 )

7) Mrs.V.A.Swami, Mrs.S.S.Kulkarni, Mr.Akshay R. Thorwate "water and soil conservation through simple techinques" (2011) (IJEST)
8) Dr. Arun B Patil and Nanda M Vibhute Watershed management for Kari River Basin a tributary of Sina River Maharashtra (IJAR) 2017

9) Mr.Ajaykumar Kadam , Dr.R.N.Sankha ,Dr Bhavana N. Umarikar Assessment of Groundwater Potential Zones using GIS Technique: acase studyof shivganga river basin pune Maharashtra (conference paper)(2016)

10) S.Modak .M.K.Verma. Mrs.C.P.Devatha Application Of Arc Gis For Estimation Of Basin Potential "A Case Study - Kharun River Basin’.(IJERT) (2012).

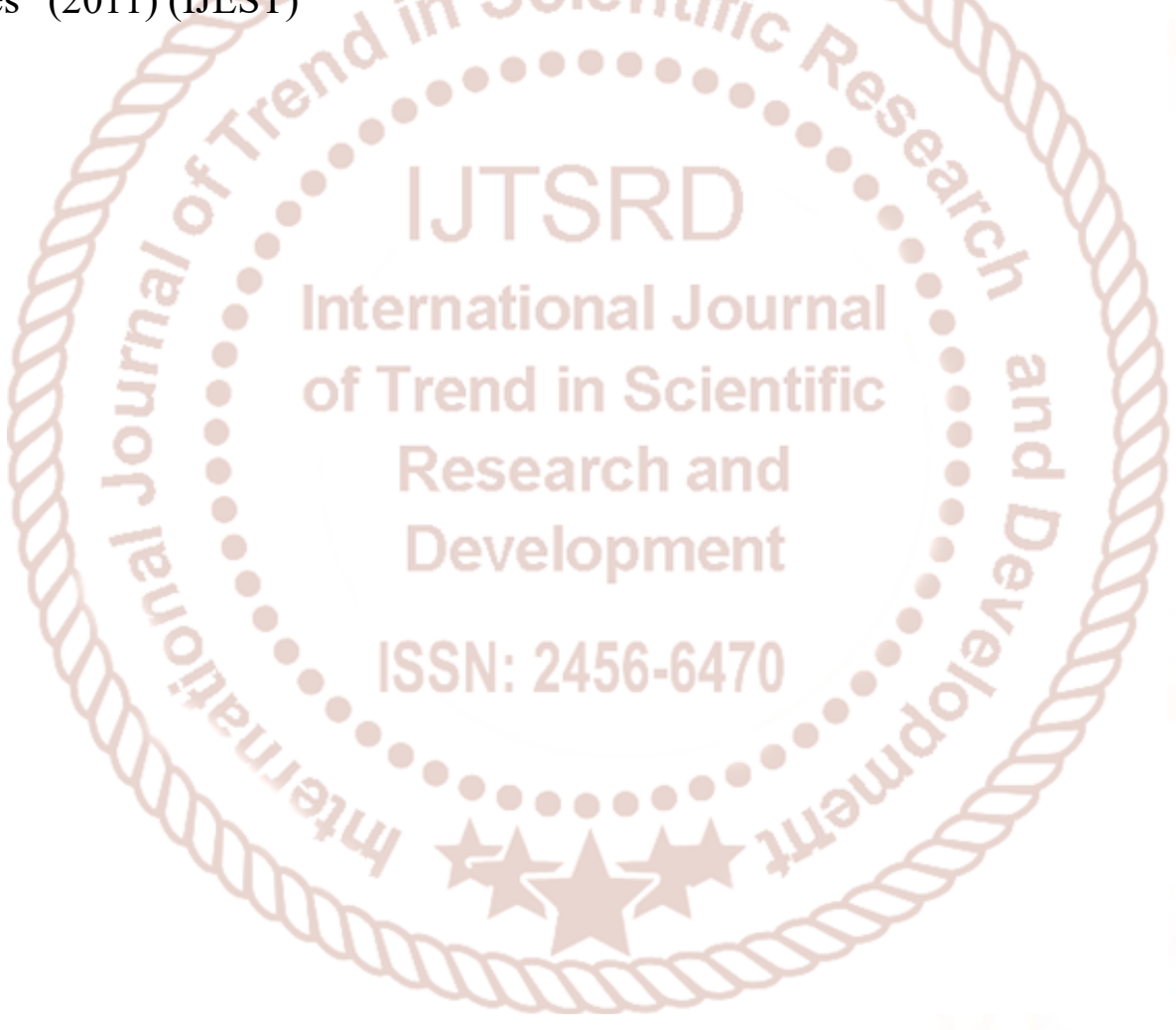

